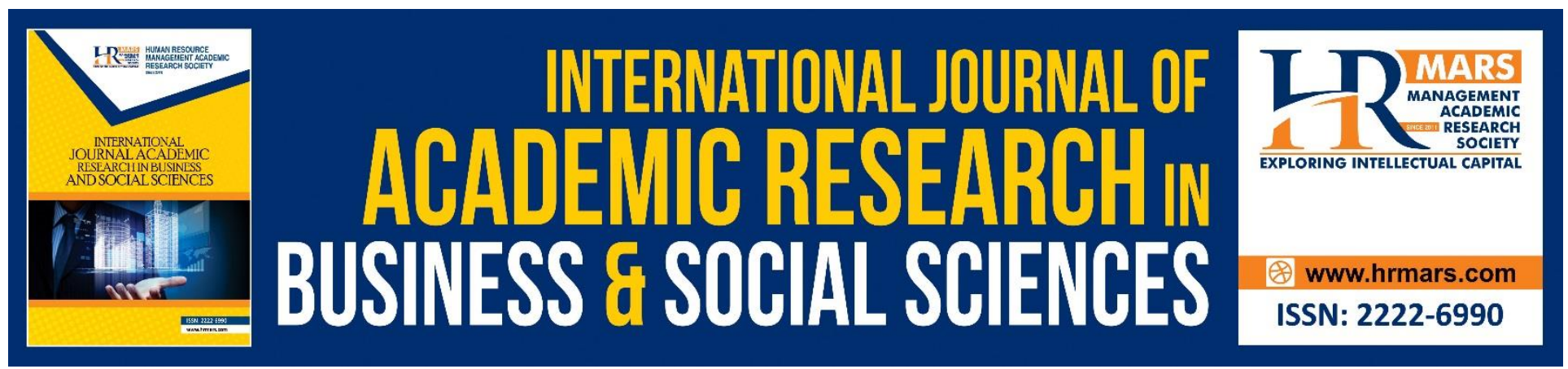

\title{
Cultural and Economic Risks Factors in UAE Construction Projects
}

\author{
Mundhir AL Hasani
}

To Link this Article: http://dx.doi.org/10.6007/IJARBSS/v8-i12/5044

DOI: $10.6007 /$ IJARBSS/v8-i12/5044

Received: 19 Oct 2018, Revised: 27 Nov 2018, Accepted: 19 Dec 2018

Published Online: 26 Dec 2018

In-Text Citation: (Hasani, 2018)

To Cite this Article: Hasani, M. AL. (2018). Cultural and Economic Risks Factors in UAE Construction Projects. International Journal of Academic Research in Business and Social Sciences, 8(12), 449-471.

Copyright: (C) 2018 The Author(s)

Published by Human Resource Management Academic Research Society (www.hrmars.com)

This article is published under the Creative Commons Attribution (CC BY 4.0) license. Anyone may reproduce, distribute, translate and create derivative works of this article (for both commercial and non-commercial purposes), subject to full attribution to the original publication and authors. The full terms of this license may be seen

at: http://creativecommons.org/licences/by/4.0/legalcode

Vol. 8, No. 12, 2018, Pg. 449 - 471

http://hrmars.com/index.php/pages/detail/IJARBSS

JOURNAL HOMEPAGE

Full Terms \& Conditions of access and use can be found at http://hrmars.com/index.php/pages/detail/publication-ethics 


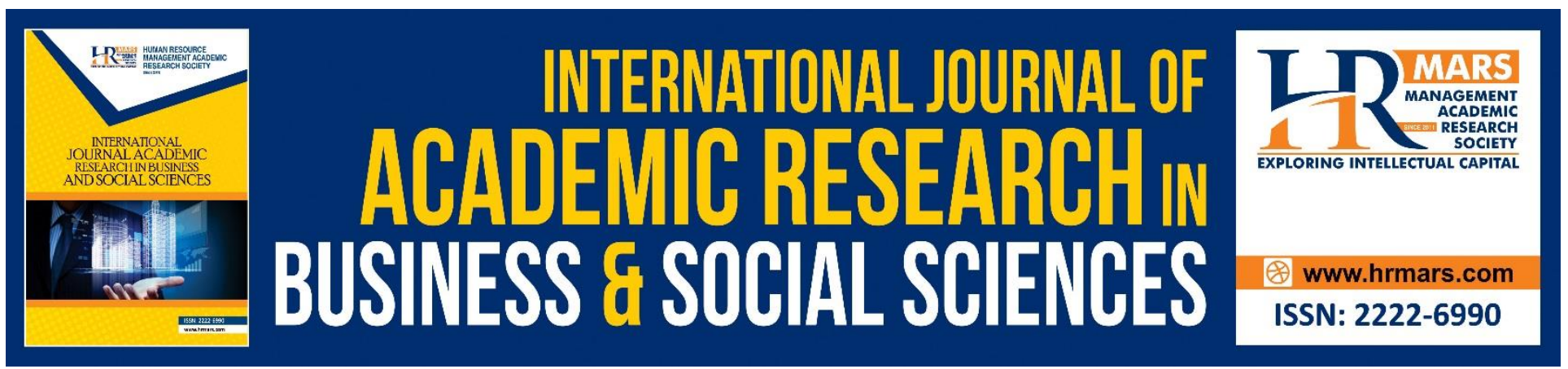

\title{
Cultural and Economic Risks Factors in UAE Construction Projects
}

\author{
Dr. Mundhir AL Hasani \\ Faculty of Society \& Design, Bond University, Queensland, Australia \\ Email: M.alhasani@student.bond.edu.au,munth4life@yahoo.com
}

\begin{abstract}
The United Arab Emirates (UAE) construction industry is an essential part of the country's economy. It provides a significant contribution to employment, housing, commercial buildings and infrastructure. The aim was to study various risks and risk factors related to success of UAE construction projects. An in-depth interview approach involving clients, contractors and consultants was used. It was noted that the differing perspectives of the three main categories of clients, contractors and consultants were critical to success, with communication factors amongst the three identified as playing a most critical role in success. A large of cultural difference was also noted within the workers in UAE industry. There was a lack of understanding of the effects and mechanisms of the risks associated with cultural diversity, including optimal ways to deal with issues and risks. Specifically, this paper identifies the major cultural and economic risks factors that impact the success of large projects.
\end{abstract}

Keywords: Cultural Risks, Economic Risks, UAE, Risk, Construction Projects

\section{Introduction}

The construction industry is an essential part of the economy due to its significant contribution to employment and the construction of new housing, commercial buildings and infrastructure, as well as the maintenance of existing structures (De Araujo et al., 2017; Yusof et al., 2016). The construction industry is one of the most risky and difficult, as well as rather effective industries in a country and tends to drive the economy more generally (Ehsan et al., 2010; Flanagan \& Norman, 1993; Ghahramanzadeh, 2013; Hanna et al., 2013; Hwang et al., 2017, 2014; lqbal et al., 2015; Liu et al., 2016; Lyons \& Skitmore, 2004; Mills, 2001; Sambasivan et al., 2017; Serpella et al., 2014; Zhi, 1995). It is characterised by intensive financial input, complex procedures, long project durations, risky environment and partner relationships (Panthi et al., 2009; Sears et al., 2015). These characteristics, along with the multi-organisational nature of construction projects, create a high-risk business environment, with a variety of risks that significantly vary across countries and from one project to another (Hwang et al., 2017). These risks may include uncertainties associated with climate and 
weather, the location and duration of projects, and even workers' motivation. However, there are other more important aspects as well, such as expertise and qualifications of the workers, communication issues amongst the various project personnel. Moreover, the local laws and regulations, and economic and financial factors, as well as a variety of local cultural and religious matters may be critical in completions of projects (Akanni et al., 2015; Al Mousli \& El-Sayegh, 2016; Kivrak et al., 2009; Zarrouk et al., 2017).

Multinational organisations often invest billions of dollars into the industry and as such are particularly prone to construction risks. This is mainly because they must navigate and consider legal and regulatory issues in different countries, not forgetting the many political matters, tradition related complications and cultural norms, as well as educational backgrounds of their different business and workplace environments (Akanni et al., 2015; El-Sayegh, 2008; Odongo et al., 2012). Navigating these challenges can be particularly difficult for Western companies which are now heavily involved in the many projects involving billions of dollars in Middle Eastern construction markets. The Middle East countries are characterised by a significantly different culture, business and workplace environments. The aim of this paper was to conduct in depth analyses of the various interactions between major players in the industry. A qualitative approach was taken, and interview data were gathered from clients, contractors and consultants in the UAE, with a major focus on the study of the nature of risks that locals consider as critical, and thus influenced the success of major construction projects.

\section{Literature review}

\section{An Overview of the UAE Construction Sector}

The construction industry is booming in the UAE, and many multinational construction companies entered the market (Bodolica et al., 2015). The construction industry is one of the most important sectors of the UAE economy, making a significant contribution to development. Through forward and backward linkages in the economy, it can also be considered an engine of economic growth. According to the UAE Ministry of Economy (2015), between 2009 and 2015, 39\% of total investment in the UAE was in construction and housing. As stated by Lopes (1998), investment in the construction sector is a major driver of economic growth, since it increases the demand for other industries such as steel, cement, electronics and machinery. Moreover, construction's wider significance for the economy can be attributed to its products and services, which generate substantial economic benefits, including the buildings in which other businesses operate (UK Construction, 2013). Statistics published by Global Market Information Databases (GMID) (2015) demonstrated that over the period of 2009 to 2015, the UAE's construction sector contributed about $11.1 \%$ to the country's gross domestic product (GDP).

More than $\$ 200$ billion are invested annually in oil, gas, power, industrial, transport, commercial and residential buildings, environment and communication construction projects (Al-Malkawi \& Pillai, 2013). This investment is occurring because demand for these products is growing (Charfeddine \& Ben Khediri, 2016). In total, approximately $\$ 5$ billion was invested in construction projects in the UAE in 2015 (Deloitte, 2015). 
INTERNATIONAL JOURNAL OF ACADEMIC RESEARCH IN BUSINESS AND SOCIAL SCIENCES Vol. 8, No. 12, Dec, 2018, E-ISSN: 2222-6990 @ 2018 HRMARS

\section{Risk in Construction Projects}

Akintoye and Macleod (1997) define construction risk as "a variable in the process of a construction project whose variation results in uncertainty as to the final cost, duration and quality of the project" (pp. 198-203). Construction projects are those that create physical infrastructure such as civil construction, residential buildings, industrial and commercial buildings, highways and utilities.

Construction is both project-based and multi-organisational, making it one of the most risky, difficult and dynamic industries (Ghahramanzadeh, 2013; Hanna et al., 2013; Hwang et al., 2017; Iqbal et al., 2015; Liu et al., 2016; Lyons \& Skitmore, 2004; Mills, 2001; Sambasivan et al., 2017; Serpella et al., 2014; Zhi, 1995). Due to construction's financial intensity, complex procedures, long project durations, risky environment and dynamic arrangements of participating organisations, it involves many different risks, and they differ from one construction project to another (Panthi et al., 2009). Aside from the risks just mentioned, there are also risks from the market situation, the level of competition, the size of the project, the expertise of the parties involved and the political, economic and cultural variations (Akintoye \& Macleod, 1997; Al-Hajj \& Sayers, 2014; Al Harthi, 2015; Altoryman, 2014; Al Mousli \& El-Sayegh, 2016; El-Sayegh, 2008, 2014; Flanagan \& Norman, 1993; Smith, 2008).

There are risks in every phase of the project life cycle and some risks may be present in more than one phase. Scholars disagree about the level of risk in the various phases of a construction project. For Chapman (1997), Godfrey (1996), Hayes et al. (1986), Harvett (2013), Hassanein and Afify (2007) and Salah and Moselhi (2016), the greatest risk is at the beginning, when there is the least information about the project and therefore the greatest uncertainty. For De Araujo et al. (2017), Lester (2017) and Zou et al. (2007), however, the construction delivery phase is even more risky than the feasibility (conceptual) phase. Still other theorists are convinced that construction risk increases from one phase of the project life cycle to the next (Al-Sabah et al., 2014; Baghdadi \& Kishk, 2015; Wang et al., 2004).

However, this depends 'very' much on the risk's potential overall effect on the project's objectives. Chapman (1997), Safa et al. (2017) and Salah and Moselhi (2016) argue that the risk is highest in the early stages because this is the stage in which it is most possible to make a fundamental 'mistake' that cannot later be corrected. In the early stages, the decisions that call for risk management are strategic decisions, which means they have significant consequences for the project's objectives. However, in the later stages, they are more likely to be tactical decisions that are likely to have less drastic consequences.

Several authors and institutes have categorised construction risks into various types and hierarchies. Akintoye and Macleod (1997), Al Harthi (2015), Baghdadi and Kishk (2015), Dziadosz and Rejment (2015), Flanagan and Norman (1993), Khodeir and Mohamed (2015), for example, proposed a broad division into (a) pure/static risks, which offer possible losses but no possible gains, and (b) dynamic/speculative risks, which offer possible gains as well as possible losses. 
Taking a different approach, Al Mousli and El-Sayegh, (2016), El-Sayegh and Mansour (2015) and Smith and Bohn (1999) divided risks into the internal and the external. Internal risk is generated inside the project and is therefore more likely to be controllable. External risk is generated outside the project and its likelihood is probably not controllable, but it may be possible to have some influence over the consequences.

Forteza et al. (2017) and Smallman (1999) suggested a classification into (a) direct risks, which included human, organisation and technological (HOT) risks, and (b) indirect risks, which included regulatory, infrastructural and political (RIP) risks. What the classification of risk into direct and indirect and the classification into internal and external had in common was that they both considered the extent to which a risk was project-specific.

Risk has also been divided into (a) subjective risk, which can be assessed on the basis of the analyst's qualitative knowledge and experience, and (b) objective risk, which can be assessed by quantitative calculation of the likelihood of a risk manifesting and impact. According to Ghahramanzadeh (2013), most of the risk in a construction project is 'subjective', due to the lack of historical data for quantitative analysis. Analysis of such risks should therefore be a matter of judgement.

Risks can also be categorised by type and impact. Al Mousli and El-Sayegh, (2016), El-Sayegh and Mansour (2015) proposed five categories: economic and financial risks, cultural diversity, external and site condition risks, technical and contractual risks and managerial risks. The project management institute [PMI] (2004) proposed a different set of four categories: technical risks, organisational risks, project risks and external risks, and the four were referred to collectively as TOPE risks. As discussed earlier, there are similarities amongst the different classifications. Both the examples just given included technical risks and external risks amongst their four categories.

However, risk of any type needs to be managed in order to avoid or mitigate the negative outcomes and to recognise the opportunities as 'quickly as possible' and be able to gain the maximum benefit from them. When a construction project begins, all risk is the client's risk. Choosing a procurement system and a contract allocates some of that risk to other parties (Safa et al., 2017). A traditional procurement system, with the parties sharing the responsibilities for the project's various phases, is meant to balance the risk amongst those parties. A design-and-build system allocates most of the risks to the contractor, who contracts to take responsibility for both the design and the construction stages. With management contracting and construction management procurement systems, the contractor mainly provides management expertise rather than execution, which leaves a lot of risk in the hands of the client (Aje et al.,2016; Hwang et al., 2014).

Given a chosen procurement system, however, the type of contract will also determine what portion of the risk is assumed by the parties involved. With a fixed price contract, the contractor takes responsibility for most of the execution and therefore takes on most of the risk. With a reimbursable contract, the contractor is paid a percentage of the cost of the project and may therefore be tempted to maximise the cost in order to maximise the profit. This leaves the client taking most of the risk; in 
particular, the financial risk. With billed rates and turnkey contracts, the contractor assumes most of the risk because they are responsible for executing most of the phases of the project. With partnership contracts, there needs to be a balance between the parties in the assumption of the project risk (Ghahramanzadeh, 2013; Hwang et al., 2017).

\section{Economic Factors}

With globalisation, more companies are doing business in multiple locations around the world and, in particular, moving into areas such as the Middle East (Al Mousli \& El-Sayegh, 2016; Khodeir \& Mohamed, 2015). The UAE is a wealthy country with a booming construction industry. Their wealth is driven mainly by the oil industry, but now also by agriculture, manufacturing and tourism (El-Sayegh \& Mansour, 2015). Twenty-five percent of GDP comes from non-oil industries. It is of note that around $24 \%$ of the construction cranes in the world today are in the UAE (Al Mousli \& El-Sayegh, 2016). In fact, the UAE's construction industry is ranked eighth in the world for construction technology, only slightly below that of the US, which ranked fifth. The UAE is ranked well above Germany, which ranked 16th (Khan, 2014).

A project's economic factors, as defined by Maina and Gathenya (2014), are 'the issues influencing the economic feasibility of the project including the changes in domestic economic conditions of the recipient country or inaccurate project development plan due to unpredictable economic conditions' (p. 154).

Economic factors such as interest rates, currency exchange rates and foreign investments or joint ventures have a large influence on projects (Al Mousli \& El-Sayegh, 2016; El-Sayegh \& Mansour, 2015; Forteza et al., 2017; Khan, 2014; Khodeir \& Mohamed, 2015; Sbia \& Alrousan, 2016). Any one of these factors could increase competition, decrease consumption or raise or lower the final sales price and the profit margin.

El-Sayegh and Mansour (2015) identified the most important economic risks for the construction industry as inflation and sudden price changes. Anton et al. (2011), Maniar (2010) and Zarrouk et al. (2017) argued that correctly forecasting inflation is necessary in order to update future costs correctly, and that lenders are better able to do this than the project's promoters. Builders also see inflation as a major risk (Papke-Shields \& Boyer-Wright, 2017).

Currency fluctuation is an important economic risk, especially for international projects (Al-Maamary et al., 2016; Babatunde \& Perera, 2017). Recently, privately financed infrastructure construction in many countries has been based on foreign capital, which if unhedged, introduced the risk of the devaluation of the local currency. International lenders generally avoided that risk, taking their payments in foreign currency. Public companies and governments used to accept the currency risk but now, with the growing demand for private financing, it is often the project's promoters, and therefore, ultimately the consumers who assumed the risk of currency depreciation. This is mainly because the lender is not willing to do so (Chen et al., 2017; Kayser, 2013; Locatelli et al., 2017). However, this can be managed. 
Changes in interest rates are also a significant economic risk for construction projects (Liu et al., 2017). Both long-term financing and short-term needs can be supplied using loans with variable interest rates. Forecasting future interest rates in order to calculate the costs of a project depends on a number of assumptions that may or may not prove true. Given the inevitable uncertainty of the global economic environment, it may be a "good idea" to adjust the project according to variable interest rates, although the predictions may never be entirely accurate (Anton et al., 2011; Zarrouk et al., 2017).

Liu et al. (2017) noted a number of other financial risks including lack of clarity in the allocation of responsibilities for the payment of certain taxes, lack of provisions for partial payment, which would reduce the risk of default, and improper withholding of guarantees on the advance payment.

Research into construction project financing in the UAE shows that local banks tend to finance landmark projects. Other financing comes from Islamic finance structures that provide a unique and culturally attractive alternative to traditional financing systems (Biygautane, 2017; Mackenzie et al., 2016; Zawawi et al., 2014). The public, government and local authority projects are usually selffinanced. Researchers have found that UAE construction projects that had traditionally been financed by the government are now increasingly likely to be financed with private investment (Mackenzie et al., 2016).

Akanni et al. (2015) identified a number of economic risks to construction projects, including access to capital, inadequate working capital, unexpected price increases for materials and labour, and changes in government policy. Others also identified delays in payment, corruption, availability of finance, cash flow, local taxes, repatriation of funds, cost overruns and changes in market demand or conditions (Ehsan et al., 2010). Akanni et al. (2015, p. 93) suggested that 'economic factors should form the focus of the management of the project environment'.

Long-term construction projects, in particular, may run a high risk of changes in the interest rate for variable loans, which is why it is so important that their risk management process includes: forecasting future interest rates (Anton et al., 2011), tax changes and the financial solvency of partners. An increase in tax rates increases financial risk by increasing the risk of loan default and the withholding of guarantees on advance payments (Liu et al., 2017). This is a high risk if the contractor has reduced its profit margin in order to win the bidding for the project (Hassim et al., 2009; Liu et al., 2017). In sum, it is crucial to understand not only the financial risks at the time the bid is placed but also those that may arise throughout the project, as these will have much to do both with project performance and with the profit margins (Mills, 2001; Sambasivan et al., 2017).

Research into economic outlook makes a clear distinction between the financial and the economic environments. According to El-Sayegh and Mansour, (2015), economic research considers how resources are used, while financial environment research considers only the money that flows from those resources. However, both factors contribute to a country's economic activity. 
Taking an economic view, it is important to understand how and how efficiently resources are used in construction projects, as a country's major economic cycles can influence its construction industry, and the success of its construction projects (Akanni et al., 2015). One responsibility of the project manager, then, is to ensure that the project is sustainable under a variety of economic conditions.

UAE's economy can be viewed as non-diversifiable economy based on the oil and construction sectors, changes in the price of oil and in the construction sector directly affect the UAE's economy. In fact, oil prices began to drop in June 2014 and, as of the first quarter of 2017, had decreased about $60 \%$ to less than $\$ 55$ a barrel; and although the International Monetary Fund has predicted the price will be $\$ 50$ a barrel in 2019 and about $\$ 60$ in 2020, this may decrease oil income as a whole in any case (According to the Dubai Statistics Center, 2017).

This economic instability has caused relatively high inflation and price fluctuation, although the high inflation can also be attributed to liquidity growth, the dependency of the UAE's central bank on the government, and inappropriate management of oil revenues. This has been compounded by the expansionary monetary policy creating liquidity growth and fostering the dependency of the central bank (Sbia \& Alrousan, 2016).

According to a report issued by the World Economic Forum, the UAE's 14.4\% inflation in 2017 was the highest of any of the countries in the GCC, followed by State of Qatar at $7.8 \%$, Saudi Arabia at 2.9\%, the Kingdom of Bahrain at 2.7\%, the Sultanate of Oman at $2.4 \%$ and Kuwait at $0.9 \%$ (World Economic Forum, 2017).

An unbalanced economy, high inflation, intense price fluctuations and budget shortages all contribute to high risk for the UAE construction industry. In the past, such cost-related (financial) issues were, for the most part, handled by adjustments in tariffs and regulations but the government has recently (2017) changed many of these rules and the new tariffs now cover only a small portion of the financial losses generated by economic issues (UAE Ministry of Infrastructure Development, 2017).

Whether or not there is a distinction between the economic and financial risks and risk factors, these factors are of major significance for the successful development of the construction industry in UAE. This is particularly the case in an oil-dependent economy, like the economy of UAE, and particularly in the presence of continuously increasing inflation. Improper management of risks in the construction industry has a significant potential to add to the current inflation pressures and further increase the existing risks in construction through a kind of 'positive feedback'. As a result, economic risks and risk factors may be particularly important for the UAE construction industry. Nonetheless, the analysis of these risks in the literature remains rather rudimentary, with no systemic approach or valid methodology enabling reliable identification and characterisation of economic risks and risk factors. 
INTERNATIONAL JOURNAL OF ACADEMIC RESEARCH IN BUSINESS AND SOCIAL SCIENCES Vol. 8, No. 12, Dec, 2018, E-ISSN: 2222-6990 @ 2018 HRMARS

\section{Cultural Factors}

There are many definitions of corporate culture in the literature. For example; Kivrak et al. (2009) argued that corporate culture includes the 'characteristics of the industry, approaches to construction, the competence of craftsmen and people who work in the industry, and the goals, values and strategies of the organizations they work in' (p. 43). Low et al. (2015) extended that definition contending that culture includes the learned, shared, symbolic traditions that shape behaviour and that these evolve over time.

A society's cultural aspects include customs, lifestyles, demographics, educational levels, norms and values, different ways of thinking, communication, different decision-making processes, different backgrounds, predominant national or tribal characteristics, different languages and different attitudes toward social responsibility (Akanni et al., 2015; Luckmann \& Farber, 2016; Yusof \& Iranmanesh, 2017). These variables can affect any organisation working within the society especially if the workers are multicultural.

The national culture also plays an important part in construction projects in UAE, due to the mix of nationalities involved in the Middle East. The culture then has significant implications for risk management. Through its interaction with the processes of cooperation and coordination, the political, institutional and social culture together affects the management style and the speed of processes undertaken (Luckmann \& Farber, 2016; Naoum et al., 2015). The cultural diversity must therefore be managed effectively in order to finish projects on time and within budget (Akanni et al., 2015). As noted, and is well known, the cultural diversity is an especially important factor in the UAE, especially where a project manager is more likely to be a foreigner than a local or national person.

Despite this, little is known about the influence of such diversity on construction projects in the UAE. What is known is that the culture of the UAE is one of high-power distance, low individualism, high uncertainty avoidance and an average level of masculinity (Hofstede et al., 1991). These characteristics offer a framework through which to study the influence of cultural differences on construction organisations, construction management, and the success of construction projects.

A recent report reveals that $88.5 \%$ of the population of the UAE are non-nationals from 132 countries (not all of whom work in construction) (UNDP, 2016). In addition to this, the use of foreign labour as a business strategy is increasing, so the number of foreign workers in the UAE is growing rapidly. Cultural diversity is therefore a key issue for any construction organisation's risk management personnel. The human resources sector may have to provide training for specialists, managers and other new employees to familiarise them with the way business is conducted in the UAE, specifically in the construction industry, in order to minimise culture shock (Khan, 2014).

All these aspects make the cultural risks and factors particularly important and may present much bigger problems for the UAE construction industry than for that industry in other countries. At the same time, the analysis of these risks in the literature still remain rather rudimentary. 
INTERNATIONAL JOURNAL OF ACADEMIC RESEARCH IN BUSINESS AND SOCIAL SCIENCES

Vol. 8, No. 12, Dec, 2018, E-ISSN: 2222-6990 @ 2018 HRMARS

Aim

The aim of this study was to undertake detailed qualitative analysis of existing risks and risk factors in the UAE construction industry. A qualitative approach focusing on clients, contractors and consultants in the industry was an appropriate method to achieve this major objective.

\section{Research Question}

- What are the major risks and risk factors (including any cultural and economic risks) on UAE construction projects?

This question was investigated by examining the differing perspectives of the three main categories of industry players clients, contractors and consultants.

\section{Methodology}

To achieve the main aim and answer the research question, this study used in depth interviews conducted with a sample of the UAE construction project personnel. The data collected was analysed qualitatively. 13 participants were conducted using a semi-structured, face-to-face interview, used to gain a deeper understanding of people's knowledge, experience and opinions. All interviewees were selected based on self-selection sampling. NVivo 11 tools was chosen as the qualitative data analysis (QDA) software for coding and analysing data in this study.

\section{Results}

All participants had to be at a senior management level in their organisations to make reasonable judgements on the risks associated with construction projects. Therefore, only high- and middle-level managerial and technical engineering staff were eligible. Thirteen semi-structured interviews were conducted, including two clients (15.4\%), six consultants (46.1\%) and five contractors (38.5\%).

\section{Cultural Risks}

It was expected that cultural issues would significantly contribute to risk management approaches in the UAE construction industry. This was supported by the fact that the cultural diversity risk factor had one of the strongest total effects on project success (Akanni et al., 2015). This motivated the commencement of the qualitative analysis starting from the consideration of risks associated with cultural issues in the UAE. Table 1 shows the nodes and sub-nodes developed for the construct of UAE culture and other groups, including their frequencies and category-relevant percentages of responses. 
INTERNATIONAL JOURNAL OF ACADEMIC RESEARCH IN BUSINESS AND SOCIAL SCIENCES Vol. 8, No. 12, Dec, 2018, E-ISSN: 2222-6990 @ 2018 HRMARS

Table 1: UAE Culture Nodes

\begin{tabular}{|c|c|c|c|c|c|}
\hline Construct & Nodes & $\begin{array}{c}\text { Client } \\
(\%) \\
\end{array}$ & $\begin{array}{c}\text { Contractor } \\
(\%)\end{array}$ & $\begin{array}{c}\text { Consultant } \\
(\%) \\
\end{array}$ & $\begin{array}{c}\text { Totals } \\
(\%)\end{array}$ \\
\hline \multirow{6}{*}{$\begin{array}{l}\text { UAE } \\
\text { culture }\end{array}$} & $\begin{array}{l}\text { Changing } \\
\text { requirements } \\
\text { without } \\
\text { considering } \\
\text { consequences }\end{array}$ & 0 & 0 & 1 (16.67\%) & $\begin{array}{c}1 \\
(7.69 \%)\end{array}$ \\
\hline & $\begin{array}{l}\text { Vertical hierarchy } \\
\text { structure }\end{array}$ & $\begin{array}{c}1 \\
(50 \%)\end{array}$ & $3(60 \%)$ & $3(50 \%)$ & $\begin{array}{c}7 \\
(53.85 \%)\end{array}$ \\
\hline & $\begin{array}{l}\text { Risk management } \\
\text { knowledge in } \\
\text { Emirates }\end{array}$ & $\begin{array}{c}1 \\
(50 \%)\end{array}$ & 0 & 1 (16.67\%) & $\begin{array}{c}2 \\
(15.38 \%)\end{array}$ \\
\hline & $\begin{array}{l}\text { Start project and } \\
\text { worry about } \\
\text { problems later }\end{array}$ & $\begin{array}{c}1 \\
(50 \%)\end{array}$ & 0 & 0 & $\begin{array}{c}1 \\
(7.69 \%)\end{array}$ \\
\hline & Trust & 0 & $2(40 \%)$ & 1 (16.67\%) & $\begin{array}{c}3 \\
(23.08 \%)\end{array}$ \\
\hline & $\begin{array}{l}\text { Risk avoidance or } \\
\text { overlooking }\end{array}$ & $\begin{array}{c}1 \\
(50 \%)\end{array}$ & 0 & 1 (16.67\%) & $\begin{array}{c}2 \\
(15.38 \%)\end{array}$ \\
\hline
\end{tabular}

Table 1 shows the outcomes of the qualitative analysis in relation to the nodes identified in association with the UAE culture construct. Nine interviewees mentioned UAE culture 27 times in their responses, which highlighted the importance of this construct for risk management and project success. Further, the vertical hierarchy of the organisational structure was identified as the most relevant (and potentially exacerbating other cultural risks) aspect of the UAE culture construct (Table 1). Other participants largely expressed similar views that vertical hierarchy organisational structure was a major factor influencing project success.

The NVivo nodes mentioned by more than $20 \%$ of the interviewees deserved special attention based on their prevalence. In this case, a $20 \%$ identification threshold was chosen to limit the number of specific risks to be considered in this study in greater detail.

The second important node within UAE culture was trust (Table 1). The interviewees found it difficult to gain the trust of local clients, and this was an important issue for the success of construction projects. The issue of trust was mentioned by three interviewees (Table 1) and was one of the specific cultural risks identified by the participants. Therefore, trust-related issues should be considered a potential risk capable of significantly affecting project success in the UAE construction industry.

The other construct that is directly relevant to cultural matters and risk factors is cultural diversity (Table 2). This construct is different from UAE culture because it reflects differences between 
INTERNATIONAL JOURNAL OF ACADEMIC RESEARCH IN BUSINESS AND SOCIAL SCIENCES Vol. 8, No. 12, Dec, 2018, E-ISSN: 2222-6990 C 2018 HRMARS

individuals from different cultures and customs who work on the same project and, at times, for the same construction company.

Table 2: Cultural Diversity Nodes

\begin{tabular}{|c|c|c|c|c|c|c|}
\hline Construct & Nodes & Sub-nodes & $\begin{array}{c}\text { Client } \\
(\%)\end{array}$ & $\begin{array}{c}\text { Contractor } \\
(\%)\end{array}$ & $\begin{array}{c}\text { Consultant } \\
(\%)\end{array}$ & $\begin{array}{c}\text { Totals } \\
(\%)\end{array}$ \\
\hline \multirow{9}{*}{$\begin{array}{l}\text { Cultural } \\
\text { diversity }\end{array}$} & $\begin{array}{l}\text { Cultural and } \\
\text { custom } \\
\text { differences }\end{array}$ & \multirow{9}{*}{$\begin{array}{l}\text { Different } \\
\text { decision- } \\
\text { making } \\
\text { processes } \\
\text { Poor } \\
\text { experience } \\
\text { in } \\
\text { decision- } \\
\text { making } \\
\text { processes }\end{array}$} & $\begin{array}{c}1 \\
(50 \%)\end{array}$ & 0 & 2 (33.33\%) & $\begin{array}{c}3 \\
(23.08 \%)\end{array}$ \\
\hline & $\begin{array}{l}\text { Different } \\
\text { languages }\end{array}$ & & $\begin{array}{c}2 \\
(100 \%)\end{array}$ & $3(60 \%)$ & 4 (66.67\%) & $\begin{array}{c}9 \\
(69.23 \%)\end{array}$ \\
\hline & $\begin{array}{l}\text { Different } \\
\text { dispute } \\
\text { resolutions }\end{array}$ & & 0 & 0 & $1(16.67 \%)$ & $\begin{array}{c}1 \\
(7.69 \%)\end{array}$ \\
\hline & & & $\begin{array}{c}1 \\
(50 \%)\end{array}$ & $2(40 \%)$ & $1(16.67 \%)$ & $\begin{array}{c}4 \\
(30.77 \%)\end{array}$ \\
\hline & $\begin{array}{l}\text { Decision } \\
\text { making } \\
\text { processes }\end{array}$ & & 0 & $1(20 \%)$ & 1 (16.67\%) & $\begin{array}{c}2 \\
(15.38 \%)\end{array}$ \\
\hline & $\begin{array}{l}\text { Different ways } \\
\text { of thinking }\end{array}$ & & 0 & $1(20 \%)$ & 0 & $\begin{array}{c}1 \\
(7.69 \%)\end{array}$ \\
\hline & $\begin{array}{l}\text { Many of } \\
\text { expatriate } \\
\text { workers }\end{array}$ & & $\begin{array}{c}1 \\
(50 \%)\end{array}$ & $2(40 \%)$ & 1 (16.67\%) & $\begin{array}{c}4 \\
(30.77 \%)\end{array}$ \\
\hline & $\begin{array}{l}\text { Emiratisation } \\
\text { process }\end{array}$ & & 0 & 0 & 2 (33.33\%) & $\begin{array}{c}2 \\
(15.38 \%)\end{array}$ \\
\hline & $\begin{array}{l}\text { High turnover } \\
\text { of } \\
\text { employment }\end{array}$ & & 0 & 0 & $1(16.67 \%)$ & $\begin{array}{c}1 \\
(7.69 \%)\end{array}$ \\
\hline
\end{tabular}

Table 2 shows the nodes and sub-nodes developed for the construct of cultural diversity, including their frequencies and category-relevant percentages of responses. The most frequently mentioned risk associated with cultural diversity was different languages (Table 2).

The other three nodes above the $20 \%$ identification threshold were cultural and custom differences (23.08\%), different decision-making processes (30.77\%) and many expatriate workers $(30.77 \%)$ (Table 2). The first of these nodes was general and did not address any specific cultural differences. Therefore, the high frequency of this node was regarded as the general corroboration of importance of the cultural diversity construct. 
INTERNATIONAL JOURNAL OF ACADEMIC RESEARCH IN BUSINESS AND SOCIAL SCIENCES Vol. 8, No. 12, Dec, 2018, E-ISSN: 2222-6990 @ 2018 HRMARS

The node large number of expatriate workers had a positive aspect that enabled more qualified workers to be hired. This demonstrated a potentially wide spectrum of opinions on expatriate workers in the UAE construction industry. Unfortunately, it did not allow reliable identification of potential risks associated with the large number of expatriate workers (apart from, and in addition to, the discussed risks associated with different languages, levels of education, culture and customs). Therefore, although the issue of large numbers of expatriate workers was frequently raised in the context of qualitative analysis (Table 2), further research is required to reliably establish whether any risks in the construction industry are associated with this issue, or whether it is a largely beneficial aspect that could be considered a reasonable tool for the management and alleviation of existing risks.

Cultural diversity risks were also involved in the external risks construct (Table 3). The association of these risks with the external risks construct was made because the risks were considered external to companies. On this basis, the following cultural nodes (cultural external risks) are associated with the external risks construct (Table 3 ): cultural differences (46.15\% response rate), different education $(38.46 \%)$, different values (30.77\%) and work culture $(30.77 \%)$. Cultural external risks were again among the highest-ranked risks within the external risks construct (Table 3). This further confirmed the widely recognised importance of cultural risks for the UAE construction industry.

Table 3: External Risk Nodes

\begin{tabular}{|c|c|c|c|c|c|}
\hline Construct & $\begin{array}{l}\text { Nodes / sub- } \\
\text { nodes }\end{array}$ & $\begin{array}{c}\text { Client } \\
(\%)\end{array}$ & $\begin{array}{c}\text { Contractor } \\
(\%)\end{array}$ & $\begin{array}{c}\text { Consultant } \\
\text { (\%) }\end{array}$ & Totals (\%) \\
\hline \multirow{12}{*}{$\begin{array}{l}\text { External } \\
\text { risks }\end{array}$} & Corruption & 0 & $2(40 \%)$ & $1(16.67 \%)$ & $3(23.08 \%)$ \\
\hline & $\begin{array}{l}\text { Market } \\
\text { demands }\end{array}$ & $1(50 \%)$ & $3(60 \%)$ & $2(33.33 \%)$ & $6(46.15 \%)$ \\
\hline & Law changes & 0 & $2(40 \%)$ & 0 & $2(15.38 \%)$ \\
\hline & $\begin{array}{l}\text { Cultural } \\
\text { differences }\end{array}$ & 0 & $3(60 \%)$ & $3(50 \%)$ & $6(46.15 \%)$ \\
\hline & $\begin{array}{l}\text { Different } \\
\text { education }\end{array}$ & 0 & $4(80 \%)$ & $1(16.67 \%)$ & $5(38.46 \%)$ \\
\hline & Knowledge & 0 & $3(60 \%)$ & $1(16.67 \%)$ & $4(30.77 \%)$ \\
\hline & Experience & 0 & $1(20 \%)$ & $1(16.67 \%)$ & $2(15.38 \%)$ \\
\hline & Lack of & & & & \\
\hline & experts and & $1(50 \%)$ & $2(40 \%)$ & $1(16.67 \%)$ & $4(30.77 \%)$ \\
\hline & $\begin{array}{l}\text { Lack of } \\
\text { experience on } \\
\text { similar projects }\end{array}$ & 0 & $1(20 \%)$ & 0 & $1(7.69 \%)$ \\
\hline & Different values & 0 & $4(80 \%)$ & 0 & $4(30.77 \%)$ \\
\hline & Work culture & 0 & $4(80 \%)$ & 0 & $4(30.77 \%)$ \\
\hline
\end{tabular}


INTERNATIONAL JOURNAL OF ACADEMIC RESEARCH IN BUSINESS AND SOCIAL SCIENCES Vol. 8, No. 12, Dec, 2018, E-ISSN: 2222-6990 @ 2018 HRMARS

\begin{tabular}{lcccc}
\hline \hline $\begin{array}{l}\text { Short notice } \\
\text { economic } \\
\text { changes }\end{array}$ & 0 & 0 & $1(16.67 \%)$ & $1(7.69 \%)$ \\
$\begin{array}{l}\text { Oil price } \\
\text { Increased }\end{array}$ & 0 & $3(60 \%)$ & $1(16.67 \%)$ & $4(30.77 \%)$ \\
$\begin{array}{l}\text { competition for } \\
\text { talent from } \\
\text { other countries }\end{array}$ & 0 & $1(20 \%)$ & 0 & $1(7.69 \%)$ \\
$\begin{array}{l}\text { Global financial } \\
\text { crisis }\end{array}$ & $1(50 \%)$ & 0 & 0 & $1(7.69 \%)$ \\
$\begin{array}{l}\text { Political and } \\
\text { social stability }\end{array}$ & 0 & $1(20 \%)$ & $2(33.33 \%)$ & $3(23.08 \%)$ \\
\hline
\end{tabular}

Table 3 shows the nodes and sub-nodes developed for the construct of external risks, including their frequencies and category-relevant percentages of responses.

Interviewees 2 (contractor), 3 (contractor), 4 (contractor) and 11 (consultant) listed cultural and educational issues and differences as the number one or number two risk among the 20 identified risks (see Table 3). This demonstrated that contractors were particularly concerned about cultural risks. It can be argued that such risks are likely to be most critical on construction sites and in dealings between contractors and other stakeholders. The critical risk of project failure was related to poor interactions between employees on site (which should be regarded as internal rather than external risks); and between project stakeholders involving contractors (which can be qualified as internal and external risks). According to the observations, contractors were more likely to be concerned about, and suffer more from (judging by their more widespread concerns) the existing cultural and educational issues and differences.

To conclude this section, it is useful to note the following comment made by Interviewee 5 (contractor): "There was a lot of willingness to say yes [to the presence of cultural differences], but not really a willingness to actually understand fully exactly what everyone was talking about so that they could progress properly". This demonstrates the current lack of progress towards a detailed understanding of the effects and mechanisms of the risks associated with cultural diversity and other cultural aspects, including optimal ways to deal with these issues and risks in the context of the UAE construction industry. One of the objectives of this study was to fill these gaps and provide a better understanding of the major cultural effects on the success of construction projects.

\section{Economic Risks}

The other major group of risks was related to economic issues. The interviewees identified several economic risks associated with different perceived constructs. For example, external risks were associated with several economic risks, including market demand, short-notice economic change, oil prices and global financial crisis (Table 4). The risks that exceeded the $20 \%$ identification threshold were market demand (46.15\%) and oil prices (30.77\%).

Thus, it is apparent that the dependence of Middle Eastern economies on oil and oil prices (including in the UAE) has a major effect on the overall economic performance of these countries and their industries, including the construction industry. The oil prices can have a drastic effect on market 
INTERNATIONAL JOURNAL OF ACADEMIC RESEARCH IN BUSINESS AND SOCIAL SCIENCES Vol. 8, No. 12, Dec, 2018, E-ISSN: 2222-6990 C 2018 HRMARS

demand, thus introducing significant risks that might not be as prevalent in other parts of the world. Alleviation of this dependence on oil prices is regarded as a priority for Middle Eastern countries, including the UAE. Oil prices it is important because they affect client's capacity (client is a governmental body in this study) to invest or worse, creates 'stop start' capital flows that lead to time and cost problems and typically budget cuts.

Table 4: Financial Risk Nodes

\begin{tabular}{|c|c|c|c|c|c|}
\hline $\begin{array}{l}\text { Construc } \\
t\end{array}$ & $\begin{array}{l}\text { Nodes / sub- } \\
\text { nodes }\end{array}$ & $\begin{array}{c}\text { Client } \\
(\%)\end{array}$ & $\begin{array}{c}\text { Contractor } \\
(\%)\end{array}$ & $\begin{array}{c}\text { Consultant } \\
(\%)\end{array}$ & Totals (\%) \\
\hline \multirow{9}{*}{$\begin{array}{l}\text { Financial } \\
\text { risks }\end{array}$} & $\begin{array}{l}\text { Foreign } \\
\text { exchange }\end{array}$ & $2(100 \%)$ & $3(60 \%)$ & 4 (66.67\%) & 9 (69.23\%) \\
\hline & Inflation & $1(50 \%)$ & $4(80 \%)$ & 4 (66.67\%) & 9 (69.23\%) \\
\hline & Interest rates & 2 (100\%) & $1(20 \%)$ & 2 (33.33\%) & 5 (38.46\%) \\
\hline & $\begin{array}{l}\text { Budget } \\
\text { issues }\end{array}$ & $2(100 \%)$ & $4(80 \%)$ & $1(16.67 \%)$ & 7 (53.85\%) \\
\hline & $\begin{array}{l}\text { Cost overrun } \\
\text { Increased (or } \\
\text { changed) }\end{array}$ & 0 & $4(80 \%)$ & $2(33.33 \%)$ & $6(46.15 \%)$ \\
\hline & $\begin{array}{l}\text { prices of } \\
\text { materials } \\
\text { and rates }\end{array}$ & $1(50 \%)$ & $3(60 \%)$ & 1 (16.67\%) & $5(38.46 \%)$ \\
\hline & $\begin{array}{l}\text { Lack of } \\
\text { financial } \\
\text { resources }\end{array}$ & $1(50 \%)$ & $1(20 \%)$ & 4 (66.67\%) & $6(46.15 \%)$ \\
\hline & $\begin{array}{l}\text { Financial } \\
\text { difficulties - } \\
\text { client, } \\
\text { owner, } \\
\text { contractor }\end{array}$ & 0 & $1(20 \%)$ & $1(16.67 \%)$ & $2(15.38 \%)$ \\
\hline & $\begin{array}{l}\text { Late } \\
\text { payments by } \\
\text { client }\end{array}$ & 0 & $2(40 \%)$ & 2 (33.33\%) & $4(30.77 \%)$ \\
\hline
\end{tabular}

Financial risks constitute part of the group of risks related to economic issues (Table 4). The most prominent and prevalent financial risks exceeding the $20 \%$ identification threshold are: foreign exchange (69.23\%), inflation (69.23\%), budget issues $(53.85 \%)$, cost overrun (46.15\%), lack of financial resources (46.15\%), interest rates (38.46\%), increased (or changed) prices of materials and rates $(38.46 \%)$ and late payments by clients $(30.77 \%)$.

Most of the budget issues were related to cost overruns, with six out of seven interviewees mentioning budget issues as a significant risk factor and focusing on cost overruns. The result was financial risks associated with oil prices, inflation, regional stability and currency exchange rates (as discussed previously). Further research is required into potential risks, associated primarily with the 
INTERNATIONAL JOURNAL OF ACADEMIC RESEARCH IN BUSINESS AND SOCIAL SCIENCES

Vol. 8, No. 12, Dec, 2018, E-ISSN: 2222-6990 @ 2018 HRMARS

government financial sources for the UAE construction industry. This factor may represent a distinction between the construction industries in the UAE and Western developed countries, which have more diverse financial sources (including private sources) for construction projects.

It might be that the UAE government should diversify financial sources for the construction industry to reduce the risks and shortcomings of mainly government financing. The Organisation for Economic Co-operation and Development (OECD) discussed methods for boosting private investors' contributions in its report entitled 'Private Financing and Government Support to Promote Long-Term Investments in Infrastructure' (OECD, 2014, p. 6). The most important factors for stimulating private investors in the construction and infrastructure industries are identified as "a clear institutional framework, transparent bidding and awarding procedures, a robust rule of law, and the absence of political interference" (OECD, 2014, p. 11).

\section{Discussion}

The findings of the three most important risk factors, including cultural diversity, external risks and economic risk, were in general agreement with some of the previous findings of the following main risks in the literature.

Cultural diversity and external risks: Vertical hierarchy of the organisational structure (Table 1), trust (Table 1), cultural diversity (different languages, cultural and custom differences and different decision-making processes) (Table 2), (cultural external risks) are associated with the external risks construct (Table 3): cultural differences, different education, different values and work culture. Cultural external risks are again among the highest-ranked risks within the external risks construct. The studies conducted by Mills (2001) in Australia, Adams (2008) in the UK, Baghdadi and Kishk (2015) in Saudi Arabia, Hassim et al. (2009) in Malaysia, Khodeir and Mohamed (2015) in Egypt, Hassanein and Afify (2007) in Egypt, Zou et al. (2007) in China, Biygautane (2017) in Kuwait, Saudi Arabia, and Qatar, Aje et al. (2016) in Nigeria have shown existence of similar issue in those countries. The finding of El-Sayegh (2014) showed that political, social and cultural risks are found to be low and insignificant in the UAE construction industry. In contrast, the findings of this study and other researchers as indicated above confirmed that, social and cultural risks are significant, and these risks may impact the success of construction projects.

Economic risks: The other major group of risks is related to economic issues mentioned by Interviewee 1: consultant, Interviewee 3: contractor and Interviewee 4: contractor. The interviewees identified several economic risks associated with different perceived constructs. For example, external risks were associated with several economic risks, including market demand, short-notice economic change and oil prices (Table 4). Financial risks constitute part of the group of risks related to economic issues (Table 4). The most prominent and prevalent financial risks are foreign exchange, inflation, budget issues, cost overrun, lack of financial resources, interest rates, increased (or changed) prices of materials and rates and late payments by clients. The findings obtained in this study are in general agreement with the findings of Al Harthi (2015) and Ghahramanzadeh (2013) 
who found that market demand, inflation, interest rates, oil prices and cost overrun are influenced the success of construction projects.

Company performance is always dependent on the economy (Flanagan \& Norman, 1993; Hwang et al., 2017). Any company will be affected by changes in the money supply, interest rate, exchange rates, government spending, trade and oil price. The construction industry is no exception.

A comparison of the findings of this study and those described in Sections 2.3 and 2.4 shows that cultural diversity risk, economic risk and external risks are not the top risks for construction projects in the countries studied in the literature. Rather, most of the critical risks for construction projects are design and technical risks; that is, internal risks. In the UAE, however, it is the economic and cultural risks that most affect construction projects, along with some external risks.

The interviews show that most of the critical risks are types of cultural, economic and financial risk. These risks are therefore much more significant for the contractor, who is responsible for the execution stage, than for the consultant and the client. It must be noted that some of these risks can be considered both the external and internal to the project, especially when-as is the case in the projects studied in this study-the client is the government. In such cases, any risk related to the client is both internal to the project, since the client is an involved party, and external, since the client is the government.

In the UAE, the economic risks most important to construction projects are cash flow, lack of financial resources, inflation, price fluctuation, oil prices and late payment, all of which can be viewed as results of economic instability. In sum, this study confirms that, risks related to economic and cultural situation of UAE influenced the projects more than other risks.

\section{Conclusion}

The UAE construction industry is an essential part of that country's economy. It provides a significant contribution to employment, housing, commercial buildings and infrastructure. The aim of this article was to study various risks and risk factors related to success in UAE construction. A qualitative indepth interview approach was considered appropriate. The interview data was gathering from clients, contractors and consultants on major projects in the industry. The study found that the differing perspectives of the three main categories of players-clients, contractors and consultants were critical to success, with communication factors amongst the three being an important and critical factor in success as in avoidance of loss in projects. A large of cultural difference was also noted within the workers in UAE industry as was predicted but most importantly there was a lack of understanding of the effects and mechanisms of the risks associated with cultural diversity. There was a lack of work done regarding optimal ways to deal with issues and risks. Essentially, this paper is a novel introduction to such research in UAE and as such identifies the major cultural and economic risks factors that affect success of large projects.

The findings of this study, including the development of the risk factors representing the common characteristics of various similar risks, will also contribute to reducing the diverse construction risks identified by other researchers and research groups (Al Mousli \& El-Sayegh, 2016, Khodeir \& Mohamed, 2015). The diversity of previous research findings is a contribution complication for the practical application of any outcomes and the development of reasonable recommendations to governments and construction managers. It originates from a lack of consensus among research 
INTERNATIONAL JOURNAL OF ACADEMIC RESEARCH IN BUSINESS AND SOCIAL SCIENCES Vol. 8, No. 12, Dec, 2018, E-ISSN: 2222-6990 @ 2018 HRMARS

groups in defining and identifying construction risks (Safa et al., 2017; Salah \& Moselhi, 2016) and from the absence of a systemic analytical approach to identifying and characterising common aspects of similar risks and their association with overarching risk constructs.

This study significantly addresses a highly important and urgent problem - the improvement of management and efficiency in the UAE construction industry. The outcomes and findings of this research (including recommendations for the government and industrial organisations) constitute a step towards the better identification, understanding, characterisation and practical management of risks in construction. These outcomes are expected to significantly improve current risk management practices in the UAE construction industry and to improve the efficiency and rate of success of current and future construction projects.

\section{References}

Adams, F.K. (2008). Construction contract risk management: A study of practices in the United Kingdom. Cost Engineering, 50(1), 22-33.

Aje, I. O., Oladinrin, T. O., \& Chibuike Nwaole, A. N. (2016). Factors influencing success rate of contractors in competitive bidding for construction works in South-East Nigeria. Journal of Construction in Developing Countries, 21(1), 19-34. doi:

http://dx.doi.org/10.21315/jcdc2016.21.1.2

Akanni, P. O., Oke, A. E., \& Akpomiemie, O. A. (2015). Impact of environmental factors on building project performance in Delta State, Nigeria. HBRC Journal, 11(1), 91-97.

doi:10.1016/j.hbrcj.2014.02.010

Akintoye, A. S., \& Macleod, M. J. (1997). Risk analysis and management in construction. International Journal of Project Management, 15(1), 31-38.

Al Harthi, B. A. (2015). Risk management in fast-track projects: A study of UAE construction projects. $\mathrm{PhD}$ thesis, University of Wolverhampton, Wolverhampton. Retrieved December $27^{\text {th }}, 2015$ from: http://hdl.handle.net/2436/579553

AL Mousli, M. H., \& El-Sayegh, S. M. (2016). Assessment of the design-construction interface problems in the UAE. Architectural Engineering and Design Management, 12(5), 353-366.

Al-Hajj, A., \& Sayers, A. (2014). Project management performance in the UAE construction industry. In computing in civil and building engineering. Proceedings of the 2014 International Conference on Computing in Civil and Building Engineering (pp. 1530-1537). American Society of Civil Engineers. doi: 10.1061/9780784413616.190

Al-Maamary, H. M. S., Kazem, H. A., \& Chaichan, M. T. (2016). The impact of oil price fluctuations on common renewable energies in GCC countries. Renewable and Sustainable Energy Reviews. doi: http://dx.doi.org/10.1016/j.rser.2016.11.079

Al-Malkawi, H., \& Pillai, R. (2013). The impact of financial crisis on UAE real estate and construction sector: Analysis and implications. Humanomics, 29(2), 115-135.

doi:10.1108/08288661311319184

Al-Sabah, R., Menassa, C. C., \& Hanna, A. (2014). Evaluating impact of construction risks in the Arabian gulf region from perspective of multinational architecture, engineering and construction firms. Construction Management and Economics, 32(4), 382-402. doi: http://dx.doi.org/10.1080/01446193.2014.884281 
INTERNATIONAL JOURNAL OF ACADEMIC RESEARCH IN BUSINESS AND SOCIAL SCIENCES

Vol. 8, No. 12, Dec, 2018, E-ISSN: 2222-6990 @ 2018 HRMARS

Altoryman, A. (2014). Identification and assessment of risk factors affecting construction projects in the Gulf region: Kuwait and Bahrain. PhD thesis, The university of Manchester, Manchester. Retrieved August 16 ${ }^{\text {th }}, 2017$ from: https://www.escholar.manchester.ac.uk/uk-ac-manscw:221966

Anton, A. J. M., Rodriguez, G. S., \& Lopez, A. R. (2011). Financial risks in construction projects. African Journal of Business Management, 5(31), 12325-12328. doi: http://dx.doi.org/10.5897/AJBM11.1463

Babatunde, S. O., \& Perera, S. (2017). Analysis of traffic revenue risk factors in BOT road projects in developing countries. Transport Policy, 56(7), 41-49. doi: http://dx.doi.org/10.1016/j.tranpol.2017.03.012

Baghdadi, A., \& Kishk, M. (2015). Saudi Arabian aviation construction projects: Identification of risks and their consequences. Procedia Engineering, 123, 32-40. doi:

http://dx.doi.org/10.1016/j.proeng.2015.10.054

Biygautane, M. (2017). Infrastructure public-private partnerships in Kuwait, Saudi Arabia, and Qatar. Public Works Management \& Policy, 22(2), 85-118. doi: http://dx.doi.org/10.1177/1087724X16671719

Bodolica, V., Spraggon, M., \& Zaidi, S. (2015). Boundary management strategies for governing family firms: A UAE-based case study. Journal of Business Research, 68(3), 684-693. doi:10.1016/j.jbusres.2014.08.003

Chapman, C. (1997). Project risk analysis and management-PRAM the generic process. International Journal of Project Management, 15(5), 273-281.

Charfeddine, L., \& Ben Khediri, K. (2016). Financial development and environmental quality in UAE: Cointegration with structural breaks. Renewable and Sustainable Energy Reviews, 55, 13221335. doi: http://dx.doi.org/10.1016/j.rser.2015.07.059

Chen, Z., Yuan, J., \& Li, Q. (2017). Financing risk analysis and case study of public-private partnerships infrastructure project. In Y. Wu, S. Zheng, J. Luo, W. Wang, Z. Mo, \& L. Shan (Eds.), Proceedings of the 20th International Symposium on Advancement of Construction Management and Real Estate (pp. 405-416). Singapore: Springer Singapore.

De Araujo, M. C. B., Alencar, L. H., \& de Miranda Mota, C. M. (2017). Project procurement management: A structured literature review. International Journal of Project Management, 35(3), 353-377. doi: http://dx.doi.org/10.1016/j.ijproman.2017.01.008

Deloitte GCC Powers of Construction. (2015). The economic barometer for the region. Retrieved April 4 ${ }^{\text {th }}, 2016$ from: https://www2.deloitte.com/content/dam/Deloitte/uk/Documents/realestate/deloitte-uk-gcc-powers-of-construction-2015.pdf

Dubai Statistics Center. (2017). Retrieved July 13 ${ }^{\text {th }}, 2017$ from: https://www.dsc.gov.ae/en-us

Dziadosz, A., \& Rejment, M. (2015). Risk analysis in construction project - Chosen Methods. Procedia Engineering, 122, 258-265. doi: http://dx.doi.org/10.1016/j.proeng.2015.10.034

Ehsan, N., Alam, M., Mirza, E. \& Ishaque, A. (2010). Risk management in construction industry. International Journal of Project Management, 61(2), 173-193.

El-Sayegh, S. M. (2008). Risk assessment and allocation in the UAE construction industry. International Journal of Project Management, 26(4), 431-438. doi: http://dx.doi.org/10.1016/j.ijproman.2007.07.004 
INTERNATIONAL JOURNAL OF ACADEMIC RESEARCH IN BUSINESS AND SOCIAL SCIENCES Vol. 8, No. 12, Dec, 2018, E-ISSN: 2222-6990 @ 2018 HRMARS

El-Sayegh, S. M. (2014). Project risk management practices in the UAE construction industry. International Journal of Project Organisation and Management, 6(1-2), 121-137. http://dx.doi:10.1504/ijpom.2014.059748

El-Sayegh, S. M., \& Mansour, M. H. (2015). Risk assessment and allocation in highway construction projects in the UAE. Journal of Management in Engineering, 31(6), 247-269. doi: http://dx.doi.org/10.1061/(asce)me.1943-5479.0000365

Flanagan, R. \& Norman, G. (1993). Risk management and construction. London: Blackwell Science Ltd.

Forteza, F. J., Carretero-Gomez, J. M., \& Sese, A. (2017). Occupational risks, accidents on sites and economic performance of construction firms. Safety Science, 94, 61-76. doi: http://dx.doi.org/10.1016/j.ssci.2017.01.003

Ghahramanzadeh, M. (2013). Managing risk of construction projects: A case study of Iran. PhD Thesis, University of East London, UK . Retrieved December 10 ${ }^{\text {th }}, 2015$ from: http://hdl.handle.net/10552/3502

GMID. (2015). Global Market Information Databases. Retrieved May 16 ${ }^{\text {th }}, 2016$ from: http://www.portal.euromonitor.com/Portal/Pages/Magazine/WelcomePage.aspx

Godfrey, P. (1996). Control of risk: A guide to the systematic management of risk from construction, construction industry research and information association, London: CIRIA.

Hanna, A. S., Thomas, G., \& Swanson, J. R. (2013). Construction risk identification and allocation: Cooperative approach. Journal of Construction Engineering and Management, 139(9), 10981107. doi: http://dx.doi.org/10.1061/(asce)co.1943-7862.0000703

Harvett, G. M. (2013). A study of uncertainty and risk management practice relative to perceived project complexity. PhD Thesis, Bond University, Gold Coast, Australia. Retrieved August $12^{\text {th }}$, 2016 from: http://epublications.bond.edu.au/theses/73/

Hassanein, A. A. G., \& Afify, H. (2007). A risk identification procedure for construction contracts - a case study of power station projects in Egypt. Civil Engineering Environmental Systems. 24(1): 3-14

Hassim, S., Jaafar, M. S., \& Sazalli, S. (2009). The contractor perception towers industrialised building Ssystem risk in construction projects in Malaysia. Journal of Social Science, 6(5): 937942.

Hayes, R., Perry, J. \& Thompson, J. (1986). Risk management in engineering construction: a guide to project risk analysis and risk management. London: Thomas Telford.

Hofstede, G. (1991). Cultures and organisations, New York, NY: McGraw-Hill.

Hwang, B. G., Zhao, X., \& Chin, E. W. Y. (2017). International construction joint ventures between Singapore and developing countries: Risk assessment and allocation preferences. Engineering, Construction and Architectural Management, 24(2), 209-228. doi: http://dx.doi.org/10.1108/ECAM-03-2015-0035

Hwang, B. G., Zhao, X., \& Toh, L. P. (2014). Risk management in small construction projects in Singapore: Status, barriers and impact. International Journal of Project Management, 32(1), 116-124. doi: https://doi.org/10.1016/j.ijproman.2013.01.007

Iqbal, S., Choudhry, R. M., Holschemacher, K., Ali, A., \& Tamošaitienė, J. (2015). Risk management in construction projects. Technological and Economic Development of Economy, 21(1), 65-78. 
INTERNATIONAL JOURNAL OF ACADEMIC RESEARCH IN BUSINESS AND SOCIAL SCIENCES Vol. 8, No. 12, Dec, 2018, E-ISSN: 2222-6990 @ 2018 HRMARS

Kayser, D. (2013). Recent research in project finance - A commented bibliography. Procedia Computer Science, 17, 729-736. doi: http://dx.doi.org/10.1016/j.procs.2013.05.094

Khan, A. (2014). Improving performance of labourers in the construction projects of UAE: A multi cultural perspective. International Journal of Indian Culture and Business Management, 9(4), 409-433. doi: http://dx.doi.org/10.1504/ijicbm.2014.065201

Khodeir, L. M., \& Mohamed, A. H. M. (2015). Identifying the latest risk probabilities affecting construction projects in Egypt according to political and economic variables. From January 2011 to January 2013. HBRC Journal, 11(1), 129-135. doi:10.1016/j.hbrcj.2014.03.007

Kivrak, S., Ross, A., Arslan, G., Tuncan, M., \& Dainty, A. (2009). Impacts of cultural differences on project success in construction. Paper presented at the Proceedings of 25th Annual ARCOM Conference, Association of Researchers in Construction Management, Nottingham, UK.

Lester, E. I. A. (2017). Chapter 8 - Project life cycles, project management, planning and control (Seventh Edition) (pp. 41-42). Oxford, United Kingdom: Butterworth-Heinemann.

Liu, J., Jin, F., Xie, Q., \& Skitmore, M. (2017). Improving risk assessment in financial feasibility of international engineering projects: A risk driver perspective. International Journal of Project Management, 35(2), 204-211. doi: http://doi.org/10.1016/j.ijproman.2016.11.004

Liu, J., Zhao, X., \& Yan, P. (2016). Risk paths in international construction projects: Case study from Chinese contractors. Journal of Construction Engineering and Management, 142(6). http://doi:10.1061/(ASCE)CO.1943-7862.0001116

Locatelli, G., Invernizzi, D. C., \& Brookes, N. J. (2017). Project characteristics and performance in Europe: An empirical analysis for large transport infrastructure projects. Transportation Research Part A: Policy and Practice, 98, 108-122. doi: http://doi.org/10.1016/j.tra.2017.01.024

Lopes, J. (1998). The construction industry and macroeconomy in Sub-Saharan Africa post 1970. Construction Management \& Economics, 16(6), 637-649.

Low, W. W., Abdul-Rahman, H., \& Zakaria, N. (2015). The impact of organizational culture on international bidding decisions: Malaysian context. International Journal of Project Management, 33(4), 917-931.

Luckmann, P., \& Farber, K. (2016). The impact of cultural differences on project stakeholder engagement: A review of case study research in international project management. Procedia Computer Science, 100, 85-94. doi: http://dx.doi.org/10.1016/j.procs.2016.09.127

Lyons, T., \& Skitmore, M. (2004). Project risk management in the Queensland engineering construction industry: A survey. International Journal of Project Management, 22(1), 51-61. doi: http://dx.doi.org/10.1016/S0263-7863(03)00005-X

Mackenzie, A., Stevens, P., Sellers, L., \& Simmons. (2016). Construction and projects in United Arab Emirates: Overview. Thomson Reuters. Retrieved March 19 $9^{\text {th }}, 2016$ from: http://uk.practicallaw.com/1-519-3663\#

Maina, C., \& Gathenya, J. (2014). Influence of economic factors on performance of project management among petroleum marketing firms in Kenya. International Journal of Academic Research in Business and Social Sciences, 4(6), 146-173. doi:

http://dx.doi.org/10.6007/IJARBSS/v4-i6/933 
INTERNATIONAL JOURNAL OF ACADEMIC RESEARCH IN BUSINESS AND SOCIAL SCIENCES

Vol. 8, No. 12, Dec, 2018, E-ISSN: 2222-6990 @ 2018 HRMARS

Maniar, H. (2010). Risk analysis of infrastructure projects: a case study on build-operate-transfer projects in India. IUP Journal of Financial Risk Management, 7(4), 34-54.

Mills, A. (2001). A systematic approach to risk management for construction. Structural survey, 19(5), 245-252. doi: http://dx.doi.org/10.1108/02630800110412615

Odongo, E. K., Agneta, N., \& Orinda, E. O. (2012). The impact of global cultural differences on the pricing strategies in United States of America. International Journal of Academic Research in Business and Social Science, 2(2), 58-68.

OECD. (2014). Private financing and government support to promote long-term investments in infrastructure. Retrieved September $27^{\text {th }}, 2017$ https://www.oecd.org/daf/fin/privatepensions/Private-financing-and-government-support-to-promote-LTI-in-infrastructure.pdf

Panthi, K., Ahmed, S. M., \& Ogunlana, S. O. (2009). Contingency estimation for construction projects through risk analysis. International Journal of Construction Education and Research, 5(2), 7994.

Papke-Shields, K. E., \& Boyer-Wright, K. M. (2017). Strategic planning characteristics applied to project management. International Journal of Project Management, 35(2), 169-179. doi: http://dx.doi.org/10.1016/j.ijproman.2016.10.015

Project Management Institute (PMI). (2004). Chapter 11- Project risk management. A guide to the project management body of knowledge $-3^{\text {rd }}$ ed. (pp. 237-268). American National Standard. Newtown Square, Pennsylvania, USA: Project Management Institute.

Safa, M., Shahi, A., Haas, C. T., \& Hipel, K. W. (2017). Construction contract management using value packaging systems. International Journal of Construction Management, 17(1), 50-64. doi: http://dx.doi.org/10.1080/15623599.2016.1167369

Salah, A., \& Moselhi, O. (2016). Risk identification and assessment for engineering procurement construction management projects using fuzzy set theory. Canadian Journal of Civil Engineering, 43(5), 429-442. doi: http://dx.doi.org/10.1139/cjce-2015-0154

Sambasivan, M., Deepak, T., Salim, A. N., \& Ponniah, V. (2017). Analysis of delays in Tanzanian construction industry: Transaction cost economics (TCE) and structural equation modeling (SEM) approach. Engineering, Construction and Architectural Management, 24(2), 308-325.

Sbia, R., \& Alrousan, S. (2016). Does financial development induce economic growth in UAE? The role of capitalization and foreign direct investment. International Journal of Economics and Financial Issues, 6(2), 703-710.

Sears, G. A., Sears, S. K., \& Clough, R. H. (2015). Construction project management (6 $6^{\text {th }}$ ed.). Somerset, US: John Wiley \& Sons, Incorporated.

Serpella, A. F., Ferrada, X., Howard, R., \& Rubio, L. (2014). Risk management in construction projects: A knowledge-based approach. Procedia - Social and Behavioral Sciences, 119, 653662. doi: http://dx.doi.org/10.1016/j.sbspro.2014.03.073

Smallman, C. (1999). Risk and organizational behaviour: A research model. Disaster Prevention and Management: An International Journal, 5(2), 12-26.

Smith, B. (2008). Ontology the blackwell guide to the philosophy of computing and information (pp. 153-166). Oxford, UK: Blackwell Publishing Ltd. 
INTERNATIONAL JOURNAL OF ACADEMIC RESEARCH IN BUSINESS AND SOCIAL SCIENCES Vol. 8, No. 12, Dec, 2018, E-ISSN: 2222-6990 @ 2018 HRMARS

Smith, G. R., \& Bohn, C. M. (1999). Small to medium contractor contingency and assumption of risk. Journal of Construction Engineering and Management, 125(2), 101-108.

http://doi:10.1061/(ASCE)0733-9364(1999)125:2(101)

UAE Ministry of Economy. (2015). The annual economic report. The twenty third edition. Retrieved December $24^{\text {th }}, 2015$ from:

http://www.economy.gov.ae/EconomicalReportsEn/MOE\%20Annual\%20Report\%20English\% 20-\%202015.pdf

UAE Ministry of Infrastructure Development. (2017). Retrieved April 9 ${ }^{\text {th }}, 2017$ from: http://www.moid.gov.ae/en-us/Pages/default.aspx

UK Construction. (2013). An economic analysis of the sector. Retrieved October $9^{\text {th }}, 2015$ from:https://www.gov.uk/government/uploads/system/uploads/attachment_data/file/2100 60/bis-13-958-uk-construction-an-economic-analysis-of-sector.pdf

UNDP. (2016). Briefing note for countries on the 2016 human development report. United Arab Emirates. Retrieved March $27^{\text {th }}, 2016$ from: http://hdr.undp.org/sites/all/themes/hdr_theme/country-notes/ARE.pdf

Wang, S. Q., Dulaimi, M. F., \& Aguria, M. Y. (2004). Risk management framework for construction projects in developing countries. Construction Management and Economics, 22(3), 237-252. doi: http://dx.doi.org/10.1080/0144619032000124689

World Economic Forum. (2017). The Global Competitiveness Report 2017-2018. Insight Report. Retrieved November 24th 2017 from:http://www3.weforum.org/docs/GCR20172018/05FullReport/TheGlobalCompetitivenessReport2017\%E2\%80\%932018.pdf

Yusof, N. A., \& Iranmanesh, M. (2017). The impacts of environmental practice characteristics on its implementation in construction project. Procedia Environmental Sciences, 37, 549-555. doi: http://doi.org/10.1016/j.proenv.2017.03.040

Yusof, N. A., Zainul Abidin, N., Zailani, S. H. M., Govindan, K., \& Iranmanesh, M. (2016). Linking the environmental practice of construction firms and the environmental behaviour of practitioners in construction projects. Journal of Cleaner Production, 121, 64-71. doi:10.1016/j.jclepro.2016.01.090

Zarrouk, H., Ghak, T. E., \& Haija, E. A. A. (2017). Financial development, Islamic finance and economic growth: evidence of the UAE. Journal of Islamic Accounting and Business Research, 8(1), 2-22. doi: http://dx.doi.org/10.1108/JIABR-05-2015-0020

Zawawi, N. A. W. A., Ahmad, M., Umar, A. A., Khamidi, M. F., \& Idrus, A. (2014). Financing PF2 Projects: Opportunities for Islamic project finance. Procedia Engineering, 77, 179-187. doi: http://dx.doi.org/10.1016/j.proeng.2014.07.015

Zhi, H. (1995). Risk management for overseas construction projects. International Journal of Project Management, 13(4), 231-237. doi: http://dx.doi.org/10.1016/0263-7863(95)00015-I

Zou, P. X. W., Zhang, G., \& Wang, J. (2007). Understanding the key risks in construction projects in China. International Journal of Project Management, 25(6), 601-614. doi:

http://doi.org/10.1016/i.ijproman.2007.03.001 